\title{
EFFECT OF THINNING ON EVAPORATION OF SCOTS PINE FOREST
}

\author{
BOCZOŃ, A.* - DUDZIŃSKA, M. - KOWALSKA, A. \\ Forest Research Institute, 3 Braci Leśnej St., 05-090 Sękocin Stary, Poland \\ *Corresponding author: \\ e-mail: a.boczon@ibles.waw.pl \\ (Received 11 $1^{\text {th }}$ Jul 2015; accepted $4^{\text {th }}$ Mar 2016)
}

\begin{abstract}
This paper presents the results of a study carried out on a Scots pine stand, aged over 70 years, growing on ICP Forests land. The stand underwent late thinning, this being the last operation performed prior to complete felling, which will take place when the trees reach an age of approximately 100 years. The thinning, which reduced the basal area by $20 \%$, caused a decrease in LAI by approximately $30 \%$ on average and an increase in the gap fraction by almost $50 \%$. The thinning of the tree canopy increased by more than $40 \%$ the quantity of light reaching the lower levels of the tree stand and the soil. Comparison of the results for actual evapotranspiration and tree transpiration with potential evapotranspiration $\left(\mathrm{T} \mathrm{ETP}^{-1}\right.$, EVT ETP ${ }^{-1}$ ) revealed an $8 \%$ increase in tree transpiration, while the actual evapotranspiration of the ecosystem increased by $14 \%$ after thinning. This increase was partly the result of the higher tree transpiration, but another factor may have been the increased evapotranspiration of forest floor vegetation and the soil, resulting from the greater quantity of light reaching the forest floor. The ratio of the pines' transpiration to the actual evapotranspiration of the ecosystem $\left(\mathrm{T} \mathrm{EVT}^{-1}\right)$ was practically unchanged, from 0.60 before thinning to 0.61 after. Modelling was also carried out (based on a Plant Water model) for average meteorological conditions to determine the effect of thinning on the rate at which the trees depleted supplies of soil water. This effect was greatest in September, when plant available water was present for 9 days longer than prior to thinning. In the months with the highest levels of transpiration (from May to August) the period in which plant available water was present lengthened by 2-3 days.

Keywords: actual evapotranspiration, ICP Forests, Pinus sylvestris, Poland, transpiration
\end{abstract}

\section{Introduction}

Thinning is an important forest management operation carried out on a very large total area every year. In Poland it is performed annually on several hundred thousand hectares of forest (for example, in 2013 the State Forests National Forest Holding carried out thinning on a total of 440000 ha; Anonim, 2013).

Thinning is carried out to improve the conditions of tree growth by reducing competition between trees for access to nutrients, water and light, and by increasing the space occupied by individual trees (Martin-Benito et al., 2010). Reducing the number of trees also affects the trees' photosynthetic activity (Gershenson et al., 2009; Högberg, 2010), root activity, and inputs of labile organic carbon (Kuzyakov, 2002; Zhu and Cheng, 2011). This leads to higher incremental growth and improved growth efficiency (Valinger et al., 2000; Pukkala et al., 2002; Mäkinen and Isomäki, 2004). Apart from its effect on tree growth, thinning also has a strong impact on the forest ecosystem. It increases the upper soil temperature and accelerates nitrogen mineralization (Thibodeau et al., 2000), increases soil moisture (Davidson et al., 2006), and makes trees more resistant to insect attack (Coyea and Margolis, 1994).

It is of interest to consider the impact of thinning on soil water conditions, particularly when forest management operations are carried out in changing climatic conditions, particularly in case of soil drought. 
The aim of this work was to determine how the thinning of an older stand of Scots pine (Pinus sylvestris L.) affected factors related to the water cycle in the ecosystem. An analysis was made of tree transpiration, the actual evapotranspiration of the ecosystem, leaf area index (LAI), light conditions, and soil water. It was also determined how thinning affects the time of soil water depletion.

\section{Materials and methods}

\section{Description of the study area}

The study was carried out in an area managed as part of the ICP Forests programme (DeVries et al., 2003), situated approximately $25 \mathrm{~km}$ south of central Warsaw, in the region overseen by the Chojnów Forest Administration. The area has poor, sandy soil of type Dystric Arenosol (IUSS Working Group WRB, 2006), with Querco-roboris Pinetum typicum (W.Mat. 1981) J.Mat. 1988 vegetation structure. The tree stand consists of 75-year-old Scots pine (as at 2013) with some birches and young oaks. The study area covered 0.42 ha, and prior to thinning contained a total of 415 trees: 358 pines, 48 oaks and 9 birches. In thinning carried out in the winter of 2012-2013, a total of 122 trees were removed (112 pines, 6 oaks and 4 birches), and the basal area was reduced from $15.2 \mathrm{~m}^{2}\left(36.2 \mathrm{~m}^{2} \mathrm{ha}^{-1}\right)$ to $12.1 \mathrm{~m}^{2}\left(28.8 \mathrm{~m}^{2} \mathrm{ha}^{-1}\right)$, representing a $20 \%$ decrease. The trees removed were chiefly those which were the most weakly developed or were entirely shaded by the canopy.

The average annual temperature in 30 last years was $8.5^{\circ} \mathrm{C}$ and average precipitation achieved the about $560 \mathrm{~mm}$ according to IMGW data for the nearest meteorological station Warszawa-Okęcie, distant about $20 \mathrm{~km}$ from the research plot.

Water circulation conditions in the area are studied in accordance with the ICP Forests methodology (Raspe et al., 2010). Measurements are made of soil moisture at depths of $10 \mathrm{~cm}, 25 \mathrm{~cm}, 50 \mathrm{~cm}$ and $85 \mathrm{~cm}$ in three soil profiles, and of throughfall. The soil moisture and throughfall are measured in 1 hour time interval. Soil retention properties were determined by plotting a $\mathrm{pF}$ curve (Table 1), and the leaf area index was calculated using hemispherical photographs. Adjacent to the area is a weather station which measures meteorological parameters in an open space in 10 minutes time interval (radiation, precipitation, air temperature on $2.0 \mathrm{~m}, 0.5 \mathrm{~m}, 0.05 \mathrm{~m}$, humidity on $2.0 \mathrm{~m}$ and $0.5 \mathrm{~m}$, wind speed and direction).

Table 1. Volumetric water content $\left[\mathrm{cm}^{3} \mathrm{~cm}^{-3}\right]$ in characteristic points of $p F$-curve [cm] of Dystric Arenosol on research plot

\begin{tabular}{c|ccccccccc}
$\begin{array}{c}\text { Depth } \\
{[\mathrm{cm}]}\end{array}$ & 0 & 1 & 1.7 & 2 & 2.5 & 3 & 3.4 & 3.7 & 4.2 \\
\hline $0-15$ & 0.457 & 0.418 & 0.282 & 0.225 & 0.112 & 0.071 & 0.059 & 0.058 & 0.045 \\
$15-30$ & 0.450 & 0.428 & 0.284 & 0.232 & 0.089 & 0.055 & 0.045 & 0.041 & 0.034
\end{tabular}




\section{Evaporation}

Evaporation was analysed in the periods from 1 May to 30 September in 2012 (before thinning) and in 2013 (after thinning) for days with complete measurement data on which soil water availability was unlimited ( $\mathrm{pF}$ between 2.0 and 3.7) and there was no rainfall. Analysed $\mathrm{pF}$ was chosen in the 2.0-3.7 range to avoid the influence of the water seeping through the soil $(\mathrm{pF}<2.0)$ and to exclude unavailable water to plants $(\mathrm{pF}$ $>$ 3.7). Evaporation was determined by the following methods:

\section{Actual evapotranspiration (EVT)}

Based on measurements of soil moisture $\left(\theta_{\mathrm{TDR}}\right)$ in 3 profiles (on 4 depths: $10 \mathrm{~cm}$, $25 \mathrm{~cm}, 50 \mathrm{~cm}, 85 \mathrm{~cm}$ ) the actual soil water supply (SWS) was determined. Daily water supply changes $(\Delta \mathrm{SWS})$ subject to the conditions: $\mathrm{pF} 2.0<\theta_{\mathrm{TDR}}<\mathrm{pF} 3.7$ : precipitation $=0 ; \Delta \mathrm{SWS}<0$ determine the value of actual daily evapotranspiration.

\section{Transpiration by pines}

The transpiration of individual pines (T) was determined based on sap flow (F) measurement using a Thermal Dissipation Probe (Dynamax Inc.). Measurements were performed on three pines (Table 2), using 2 sensors per tree. Based on the measured rate of water flow in the tree stem $(\mathrm{V})$, the computed white cross-sectional area $\left(\mathrm{A}_{\mathrm{sw}}\right)$ and the area of the projection of the crowns of individual trees $\left(A_{c}\right)$, the tree transpiration (T) was calculated:

$$
\begin{aligned}
& \mathrm{F}=\mathrm{V} \cdot \mathrm{A}_{\mathrm{sw}}\left[\mathrm{dm}^{3} \mathrm{~s}^{-1}\right] \\
& \mathrm{T}=\mathrm{F} \cdot \mathrm{A}_{\mathrm{c}}{ }^{-1}[\mathrm{~mm}]
\end{aligned}
$$

Table 2. Characteristics of examined Scots pines

\begin{tabular}{c|ccc} 
& DBH $(\mathrm{cm})$ & Height $(\mathrm{m})$ & Crown Position Class \\
\hline Pine no 1 & 22.5 & 19.0 & Co-dominant \\
Pine no 2 & 25.3 & 20.5 & Dominant \\
Pine no 3 & 24.3 & 20.5 & Dominant
\end{tabular}

\section{Potential evapotranspiration (ETP)}

Calculation of the potential evapotranspiration makes it possible to determine how the meteorological conditions affect the process of evaporation. Potential evapotranspiration was computed by means of the Penman-Monteith formula (Allen et al., 1998).

\section{Effect of drought - modelling}

A criterion for determining the effect of thinning on the occurrence of soil drought was taken to be the time in which the trees deplete the supply of soil water in the useful 
retention range (from $\mathrm{pF} 2.0$ to $\mathrm{pF} 3.7$ ). In the case of Scots pine, the mass of the small roots responsible for water uptake is mainly located in the upper soil layer (Janssens et al., 2002). Changes in water supply were therefore analysed down to a soil depth of $0.25 \mathrm{~m}$. The computed soil water supply in that layer was $43.4 \mathrm{~mm}$. The trees' uptake of water was calculated using the Plant Water model, one of the group of Soil-PlantAtmosphere-Continuum models (Kowalik and Turner, 1983; Kowalik and Eckersten, 1984). A detailed description of the model is contained in Kowalik et al. (1987). In the Plant Water model, a plant is regarded as a water reservoir through which water flow takes place as a result of the loss of easily exchangeable water in the transpiration process $\left(\mathrm{T}, \mathrm{g} \mathrm{m}^{-2} \mathrm{~s}^{-1}\right)$ and the inflow of water taken up by the roots $\left(\mathrm{U}, \mathrm{g} \mathrm{m}^{-2} \mathrm{~s}^{-1}\right)$. The plant's water content $(\mathrm{V})$ is given by the formula:

$$
\mathrm{V}=\mathrm{V}_{\mathrm{i}}+\int_{0}^{\tau}(\mathrm{U}-\mathrm{T}) \mathrm{d} \tau\left[\mathrm{g} \mathrm{m}^{-3}\right]
$$

where $V_{i}$ is the plant's initial water content, and $d \tau$ is the time interval after which the changes are considered.

The uptake of water through the root system (U) is calculated from the flowproducing gradient of potentials of leaf water $\left(\psi_{1}, \mathrm{MPa}\right)$ and of soil water $\left(\psi_{\mathrm{s}}, \mathrm{MPa}\right)$, taking account of the resistances encountered by the flowing water, using the formula:

$$
\mathrm{U}=\frac{\psi_{\mathrm{s}}-\psi_{1}}{\mathrm{r}_{\mathrm{r}}+\mathrm{r}_{\mathrm{p}}}\left[\mathrm{g} \mathrm{m}^{-2} \mathrm{~s}^{-1}\right]
$$

where $r_{r}$ is the resistance to the flow of water between the soil and root $\left(\mathrm{MPa} \mathrm{m}^{2} \mathrm{~s} \mathrm{~g}^{-1}\right)$, and $r_{p}$ is the resistance of the plant's vascular bundles $\left(\mathrm{MPa} \mathrm{m}^{2} \mathrm{~s} \mathrm{~g}^{-1}\right)$.

Modelling was carried out for the months from April to September, applying the average meteorological parameters recorded at the weather station in those months (Table 3).

Table 3. Average meteorological conditions for the days subject to modelling

\begin{tabular}{l|ccccc} 
& Mai & June & July & August & September \\
\hline Air temperature $\left[{ }^{\circ} \mathrm{C}\right]$ & 13.2 & 16.7 & 18.0 & 17.2 & 12.0 \\
Humidity [\%] & 74.5 & 77.9 & 74.7 & 76.3 & 83.5 \\
Radiation $\left[\mathrm{W} \mathrm{m}^{-2}\right]$ & 124.2 & 143.0 & 148.6 & 120.2 & 65.8
\end{tabular}

\section{LAI, gap fraction, light conditions}

The leaf area index of the tree stand, the gap fraction, and the solar radiation below canopy were determined from hemispherical photographs, which were analysed using Hemiview software. The photographs were taken before and after thinning, during the period of maximum leaf area, at the same 10 points. During the 
study period no other foliage - reducing factors (insects, pathogen, drought, pollution, etc.) were identified.

\section{Statistics}

The distribution of EVT, ETP and T are non-normal. The significance of the differences in EVT, T, EVT ETP ${ }^{-1} \mathrm{~T} \mathrm{ETP}^{-1}$ and $\mathrm{T} \mathrm{EVT}^{-1}$ before and after thinning was tested using Mann-Whitney test.

\section{Results and discussion}

Thinning leads to a reduction in the number of trees and the density of the canopy. Parameters providing a good description of a tree canopy are the leaf area index (LAI) and the gap fraction. The LAI is defined as the surface area of green leaves and needles per unit horizontal area of ground (Watson, 1947). This parameter concerns the main surfaces on which carbon dioxide and water are exchanged between the upper layer of the crown and the atmosphere. It is also a key variable for the functioning of the ecosystem. Many processes taking place in forests depend on the LAI, including rain and light interception (Gash, 1979), tree stand productivity (Davi et al., 2006), transpiration (Granier et al., 2000), and soil respiration (Davidson et al., 2002). Spatial differences in LAI are correlated with evapotranspiration and soil moisture (Grier and Running, 1977; Long and Smith, 1990; Burton et al., 1991; Jose and Gillespie, 1997). Thinning which reduced the basal area by $20 \%$ caused a decrease in LAI by approximately $30 \%$ on average, and an increase in the gap fraction by almost $50 \%$ (Table 4). The thinning of the canopy brought about an increase by more than $35 \%$ in the quantity of light reaching the lower layers of the trees and the soil.

Table 4. Leaf Area Index (LAI). gap fraction (\%) and radiation below canopy $\left(R_{b c}, M J m^{-2}\right.$ year $\left.{ }^{-1}\right)$ before and after thinning

\begin{tabular}{l|lll|lll|lll}
$\begin{array}{l}\text { No. } \\
\text { hemispheric } \\
\text { image }\end{array}$ & \multicolumn{3}{|c|}{ Before thinning } & \multicolumn{3}{|c|}{ After thinning } & \multicolumn{3}{|l}{ Percentage of change [\%] } \\
& fraction & LAI & $\mathrm{R}_{\mathrm{bc}}$ & $\begin{array}{l}\text { Gap } \\
\text { fraction }\end{array}$ & LAI & $\mathrm{R}_{\mathrm{bc}}$ & $\begin{array}{l}\text { Gap } \\
\text { fraction }\end{array}$ & LAI & $\mathrm{R}_{\mathrm{bc}}$ \\
\hline 1 & 6.6 & 2.60 & 396 & 23.7 & 1.45 & 1493 & 259.5 & -44.2 & 277.0 \\
2 & 7.6 & 2.60 & 458 & 23.6 & 1.51 & 1360 & 210.9 & -42.1 & 196.7 \\
3 & 15.6 & 1.95 & 1042 & 17.9 & 1.49 & 1051 & 14.8 & -23.4 & 0.9 \\
4 & 19.8 & 1.68 & 1382 & 20.4 & 1.43 & 1228 & 3.0 & -15.0 & -11.1 \\
5 & 17.9 & 1.92 & 1202 & 21.9 & 1.47 & 1246 & 22.1 & -23.4 & 3.7 \\
6 & 11.9 & 2.26 & 829 & 19.4 & 1.73 & 1204 & 62.1 & -23.3 & 45.3 \\
7 & 10.0 & 2.43 & 714 & 17.4 & 1.71 & 1160 & 73.0 & -29.7 & 62.5 \\
8 & 16.9 & 2.04 & 1228 & 18.1 & 1.37 & 1055 & 7.0 & -32.5 & -14.0 \\
9 & 14.6 & 2.19 & 918 & 22.0 & 1.32 & 1270 & 51.3 & -39.6 & 38.3 \\
10 & 17.5 & 1.99 & 1170 & 21.3 & 1.46 & 1221 & 21.8 & -26.7 & 4.4 \\
\hline Mean & 13.9 & 2.17 & 934 & 20.6 & 1.49 & 1229 & 48.5 & -31.0 & 31.6
\end{tabular}


The persistence of the effects of canopy density reduction depends on the rate of crown growth. The growth of crowns to fill available space has been observed in the case of pine as well as other trees (Baldwin et al., 2000; Lockow, 2003). However the incremental growth of the crowns is smaller in older trees than in younger ones. A study by Juodvalkis et al. (2005) showed that a very significant rise in the increment of crown volume can be achieved through thinning in the case of young trees - for example, those aged 10-20 years in the case of pines. For older trees, crown growth will fall to below $10 \%$. It can therefore be expected that the increase in throughfall will persist for longer in the case of older trees, but with younger ones, because of the higher rate of crown growth, the effect will persist for a significantly shorter time.

Many researchers have reported that larger quantities of precipitation reaching the soil may be one of the chief factors behind the increase in the available soil water supply following thinning (Zahner and Whitmore, 1960; Cregg et al., 1990; Stogsdill et al., 1992; Breda et al., 1995; Baumler and Zech, 1997;). They also identify reduced evapotranspiration or transpiration as a second factor. The effect of thinning on transpiration has been studied by many authors, but there are discrepancies in the results reported. Breda et al. (1995) found a relationship between reduced tree transpiration and reduced basal area in stands of Quercus petraea (Matt.) Liebl. A similar result was obtained by Morikawa et al. (1986) in a stand of Chamaecyparis obtusa Endl. However, in a study of transpiration in Pseudotsuga menziesii (Mirb.) Franco, conducted by Black et al. (1980), thinning was found to have little or no effect on tree transpiration. A similar result was obtained for a stand of Pinus taeda L. (Stogsdill et al., 1992), and in a study of Pinus sylvestris L. Vesala et al. (2005) also found that thinning did not affect the total tree transpiration.

The present study of changes in transpiration in pines and in the evapotranspiration of the pine ecosystem indicates that these processes intensify following thinning (Fig. 1). Transpiration in the pines showed a statistically significant increase $(\mathrm{p}=0.0012)$ of $41 \%$, while actual evapotranspiration increased by $42 \%$, which was again statistically significant $(\mathrm{p}=0.00005)$. The ratio of the pines' transpiration to the evapotranspiration of the ecosystem $\left(\mathrm{T} \mathrm{EVT}^{-1}\right)$ was practically the same before and after thinning, amounting to 0.58 before thinning and 0.60 after (difference not statistically significant, $\mathrm{p}=0.4547$ ). The change in conditions following thinning had an equal effect on the transpiration of individual trees and on the evapotranspiration of the whole ecosystem (Table 5). This finding also indicates the relatively low water requirements of the Scots pine. It is possible that the fact that the pines do not use up all of the water available at a given time is one of the main factors that have enabled that species to take hold in a wide range of forest habitats, from extremely dry to marshy.

Table 5. Median values of potential evapotranspiration (ETP), actual evapotranspiration (EVT), transpiration of trees (T), and relations between ETP, EVT and T

\begin{tabular}{c|cccccc} 
& \multicolumn{6}{|c}{ Parameter } \\
& $\begin{array}{c}\text { ETP } \\
{[\mathrm{mm}]}\end{array}$ & $\begin{array}{c}\text { EVT } \\
{[\mathrm{mm}]}\end{array}$ & $\begin{array}{c}\mathrm{T} \\
{[\mathrm{mm}]}\end{array}$ & EVT ETP $^{-1}$ & T ETP $^{-1}$ & T EVT $^{-1}$ \\
\hline Before thinning & 3.36 & 1.74 & 1.06 & 0.48 & 0.32 & 0.58 \\
After thinning & 3.48 & 2.48 & 1.50 & 0.65 & 0.39 & 0.60
\end{tabular}


Before thinning
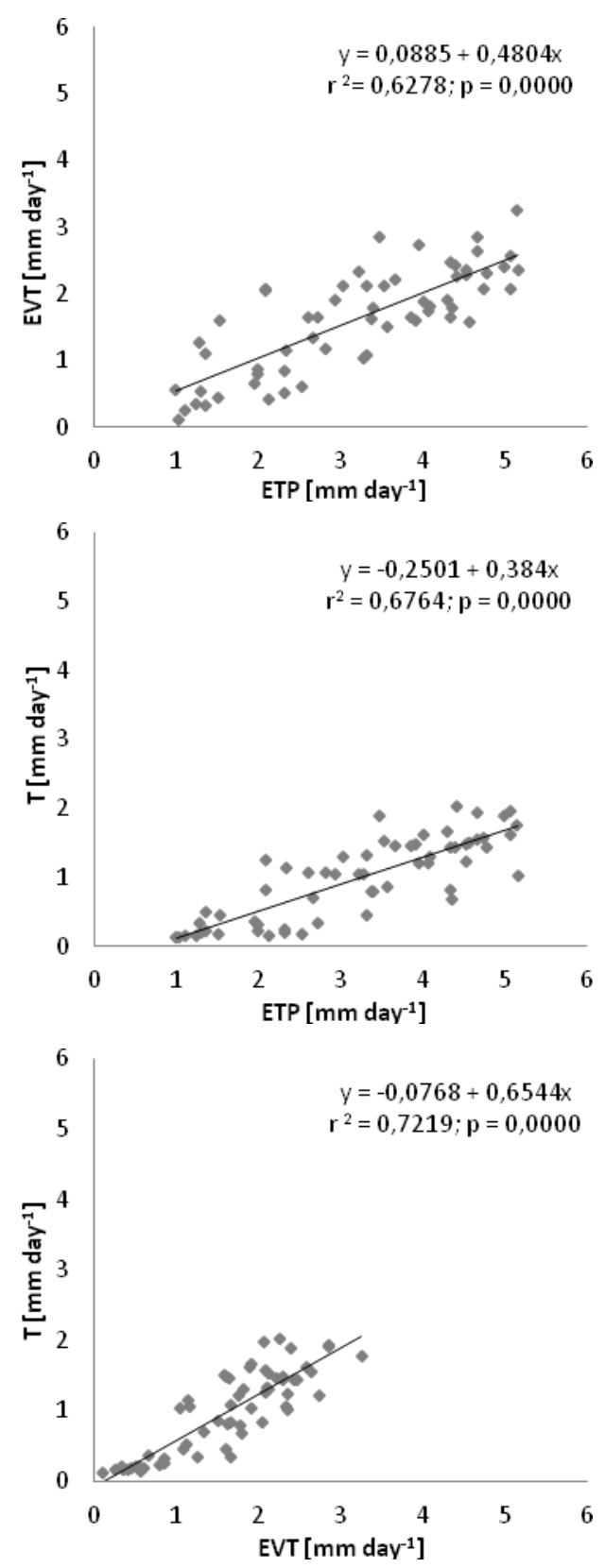

After thinning
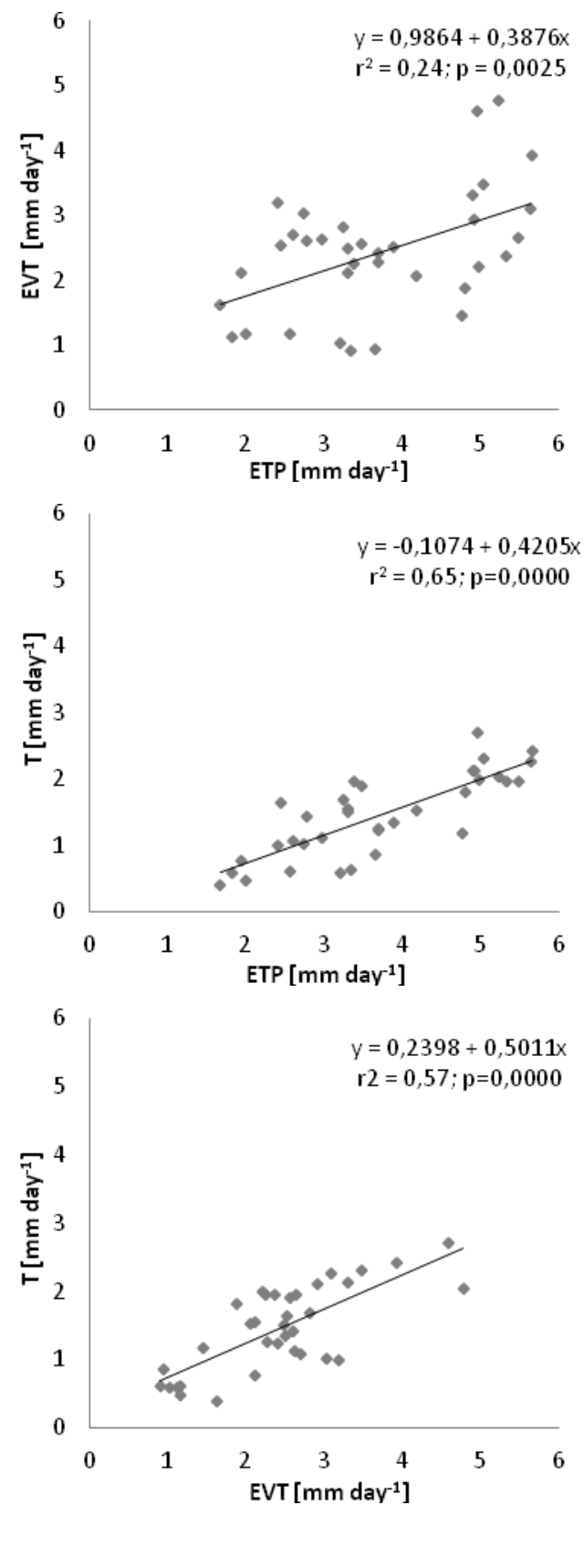

Figure 1. Relationships between transpiration. actual evapotranspiration. potential evapotranspiration before and after the forest thinning

Comparison of the results with potential evapotranspiration (difference not statistically significant, $\mathrm{p}=0.1199$ ), which provides an analysis for similar meteorological conditions determining the evaporation process, shows that tree transpiration increased by $22 \%$ (the ratio $\mathrm{T} \mathrm{ETP}^{-1}$ was 0.32 before and 0.39 after thinning; difference statistically significant, $p=0.0003$ ). The reason for this may be the reduction in the density of the crowns, which entails not only an increase in the growth 
space for individual trees, but possibly also the creation of improved conditions for transpiration. After thinning, a greater quantity of light reaches the crowns (Whitehead et al., 1984), and the creation of space between the crowns favours better exchange of water vapour and its rising above the crowns. Ensuring increased accessibility of light to the tree crowns is one of the reasons for which thinning is carried out; the growth of trees is thus accelerated by creating better conditions for photosynthesis. At the same time, better conditions are created for tree transpiration.

Evapotranspiration of the ecosystem showed a 35\% increase following thinning (the ratio EVT $\mathrm{ETP}^{-1}$ was 0.48 before and 0.65 after thinning (difference statistically significant, $\mathrm{p}=0.0005$ ). In this case, the increase resulted partly from the higher tree transpiration, but another contributing factor may have been increased evapotranspiration of forest floor vegetation and the soil, as a result of the greater quantity of light reaching the forest floor. An increase in ecosystem evapotranspiration following a significant decrease in LAI was also observed by Knoche (2005).

An increased quantity of light penetrating through the tree canopy, along with increased soil moisture, will stimulate the development of lower vegetation layers. Lüttschwager et al. (1999) note the great importance of the ground layers of vegetation for evapotranspiration in pine stands, as do Müller et al. (1998). They showed that forest ground cover dominated by such species as Calamagrostis epigejos (L.) Roth and Deschampsia flexuosa (L.) Trin can, in favourable conditions, transpire up to almost $50 \%$ of the total water uptake of the forest ecosystem. A characteristic feature of these ground layer species is their high light requirement, hence a large reduction in the tree canopy may have a favourable effect on the occurrence and development of those species following thinning, which will lead to an increase in the total evapotranspiration of the forest ecosystem.

An important challenge faced by foresters in central Europe is the need to adapt tree stands to the effects of climate changes. It is projected that such changes will lead to warmer weather and lower rainfall during the vegetation period in central Europe (Degirmendžić et al., 2004; Briffa et al., 2009; Dubrovsky et al., 2009;). As a result, insufficiency of water in the environment will become more common, particularly in habitats with weak sandy soils with a deep groundwater level. Thinning, i.e. reducing the density of tree stands, may be a way of adapting the forest to the changing climate (Misson et al., 2003; Martin-Benito et al., 2010). Whitehead et al. (1984) believe that thinning will reduce the susceptibility of tree stands to drought, by reducing interception and increasing the soil water supply. Similar conclusions have been reported by Aussenac and Granier (1988) and Gracia et al. (1999). Thinning has been found to have a positive impact on drought stress in a study of 32-year-old black pines in Spain (Martin-Benito et al., 2010) and in 22-year-old spruce in the Belgian Ardennes (Misson et al., 2003).

The modelling performed here for average meteorological conditions, neglecting the effect of thinning on microclimate, showed that the number of days on which the pines deplete the soil water supply to a state in which no water is available to plants is greatest at the start and at the end of the vegetation season. There is similar variation in the number of additional days of water availability following thinning. The effect of the reduction in tree density was greatest in September, when available water was present for 9 days longer than was the case prior to thinning. In the months with the highest levels of transpiration (May to August) the time for which available water was present increased by 2 or 3 days (Fig. 2) 


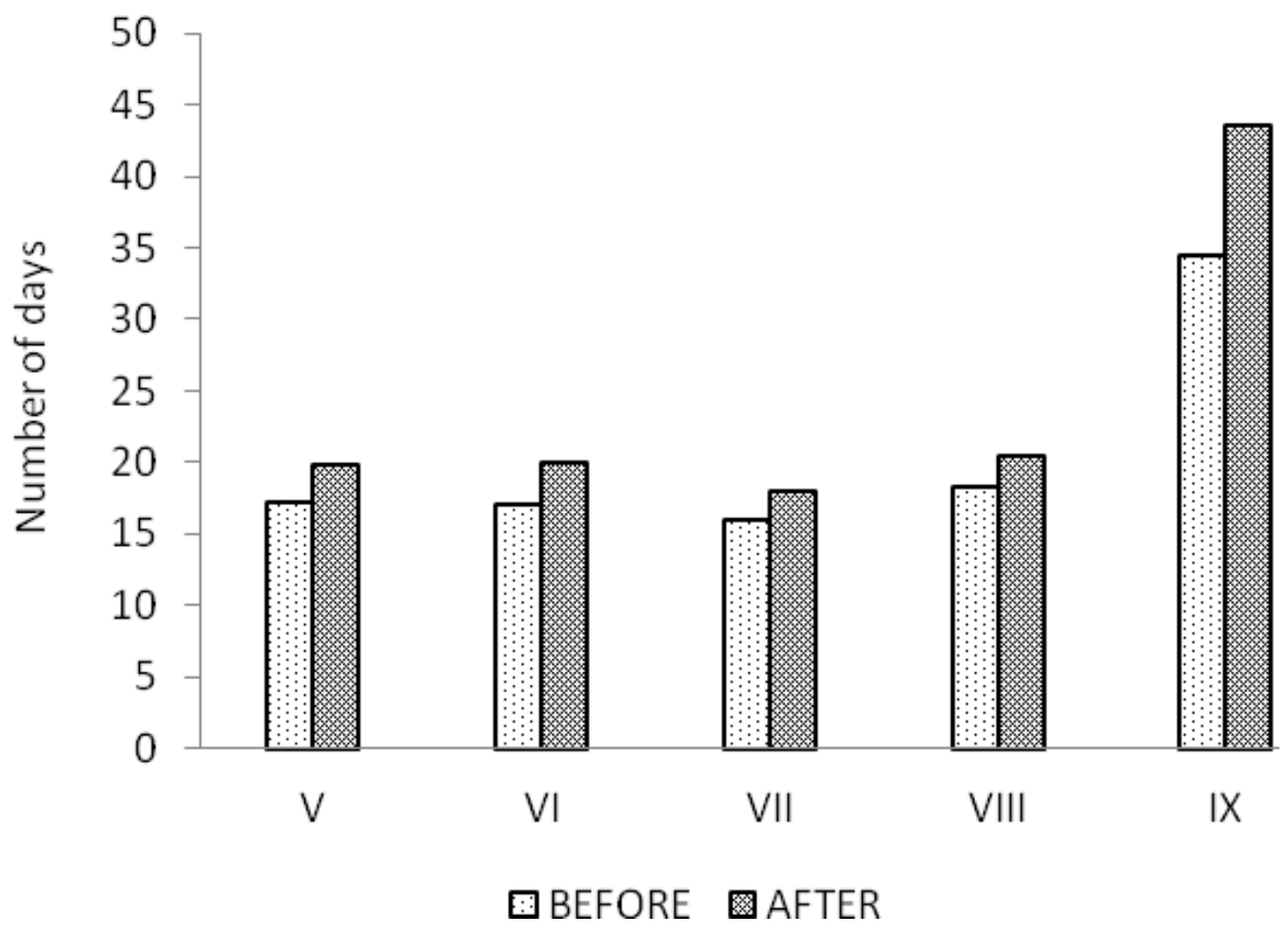

Figure 2. Number of days on which the pine stand depleted the supply of soil water within the useful retention range (from $\mathrm{pF}=2.0$ to $\mathrm{pF}=3.7$ ) before and after thinning from May $(V)$ to September (IX)

The relatively small change in the length of the period in which plant available water was present may be of great importance for the tree stand's survival in rainless periods. In particular, Lagergren and Lindroth (2002) showed that a decrease in available soil water content (SWC) greatly reduces transpiration in pines, and hence even a small increase in SWC will have a strong impact on a stand's transpiration ability.

However, the modelling of meteorological conditions does not take account of micrometeorological changes occurring in the tree stand after thinning. These changes will lead to an increase in tree transpiration and the evapotranspiration of the ecosystem, as described above. Therefore, in order to draw accurate conclusions, it is necessary to carry out a study within the tree stand itself, although this may be difficult in view of the very high variability of the meteorological conditions found within the stand.

\section{Conclusions}

Reducing the number of trees will lead to a decrease in transpiration, and consequently a decrease in the evapotranspiration of a forest ecosystem. However, this study has shown that thinning in fact causes an increase both in the transpiration of individual trees and in the actual evapotranspiration of the ecosystem. Although thinning reduces the total transpiring leaf area, the reduction in the density of the canopy creates better conditions for intensity of transpiration, by increasing the quantity of solar radiation reaching the tree crowns, and also facilitates the rising of water vapour above the crowns. The actual evapotranspiration of the ecosystem is increased partly 
due to the greater tree transpiration, but another factor may be the higher transpiration of forest floor vegetation and soil evaporation, caused by the greater quantity of light penetrating the tree canopy. The contribution of the transpiration of the Scots pine to the evapotranspiration of the ecosystem was at a similar level of around 0.60 both before and after thinning.

A model-based study of the lengthening of the time in which soil water was available to plants showed that thinning produced a positive effect. It should be borne in mind, however, that the study was based on data from a weather station situated outside the forest. Thinning strongly modifies the micrometeorological conditions existing within a tree stand. Hence modelling based on data from standard weather stations may carry a certain degree of error.

Acknowledgments. This work was supported by The Polish State Forests National Forest Holding [grant number 500404].

\section{REFERENCES}

[1] Allen, R.G., Pereira, L.S., Raes, D., Smith, M. (1998): Crop EvapotranspirationGuidelines for Computing Crop Water Requirements. - FAO Irrigation \& Drainage Paper 56. FAO.

[2] Anonim (2013): THE STATE FORESTS IN FIGURES 2013. - The State Forests Information Centre, Warsaw (http://www.lasy.gov.pl/publikacje/in-english/the-stateforests-in-figures-2013)

[3] Aussenac, G., Granier, A. (1988): Effects of thinning on water stress and growth in Douglas-fir. - Canadian Journal of Forest Research 18: 100-105.

[4] Baldwin, V.C.Jr., Peterson, K.D., Clark, III.A., Ferguson, R.B., Strub, M.R., Bower, D.R. (2000): The effects of spacing and thinning on stand and tree characteristics of 38-yearold lobolly pine. - Forest Ecology and Management 137: 91-102

[5] Baumler, R., Zech, W. (1997): Atmospheric deposition and impact of forest thinning on the throughfall of mountain forest ecosystems in the Bavarian Alps. - Forest Ecology and Management 95: 243-251.

[6] Black, T.A., Tan, C.S., Nnyamah, J.U. (1980): Transpiration rate of Douglas fir trees in thinned and unthinned stands. - Canadian Journal of Soil Science 60: 625-631.

[7] Breda, N., Granier, A., Aussenac, G. (1995): Effects of thinning on soil and tree water relations, transpiration and growth in an oak forest (Quercus petraea (Matt.) Liebl.). Tree Physiology 15: 295-306.

[8] Briffa, K.R., van der Schrier, G., Jones, P.D. (2009): Wet and dry summers in Europe since 1750: evidence of increasing drought. - International Journal of Climatology 29: 1894-1905, doi:10.1002/joc.1836.

[9] Burton, A.J., Pregitzer K.S., Reed, D.D. (1991): Leaf area and foliar biomass relationships in northern hardwood forests located along an $800 \mathrm{~km}$ acid deposition gradient. - Forest Science 37 (4): 1011-1059.

[10] Coyea, M.R., Margolis, H.A. (1994): The historical reconstruction of growth efficiency and its relationship to tree mortality in balsam fir ecosystems affected by spruce budworm. - Canadian Journal of Forest Research 24 (11): 2208-2221.

[11] Cregg, B.M., Hennessey, T.C., Dougherty, P.M. (1990): Water relations of loblolly-pine trees in southeastern Oklahoma following precommercial thinning. - Canadian Journal of Forest Research 20: 1508-1513.

[12] Davi, H., Bouriaud, O., Dufrêne, E., Soudani, S., Pontaillier, J.Y., le Maire, G., Francois, C., Bréda, N., Granier, A., le Dantec, V. (2006): Effect of aggregating spatial parameters 
on modelling forest carbon and water fluxes. - Agricultural and Forest Meteorology 139: 269-287.

[13] Davidson, E.A., Janssens, I.A., Luo, Y. (2006): On the variability of respiration in terrestrial ecosystems: moving beyond Q10. - Global Change Biology 12 (2): 154-164.

[14] Davidson, E.A., Savage, K., Bolstad, P., Clark, D.A., Curtis, P.S., Ellsworth, D.S., Hanson, P.J., Law, B.E., Luo, Y., Pregitzer, K.S., Randolph, J.C., Zak, D. (2002): Belowground carbon allocation in forests estimated from litterfall and IRGA-based soil respiration measurements. - Agricultural and Forest Meteorology 113: 39-54.

[15] Degirmendžić, J., Kożuchowski, K., Żmudzka, E. (2004): Changes of air temperature and precipitation in Poland in the period 1951-2000 and their relationship to atmospheric circulation. - International Journal of Climatology 24: 291-310.

[16] De Vries, W., Reinds, G.J., Vel, E. (2003): Intensive monitoring of forest ecosystems in Europe 2: Atmospheric deposition and its impacts on soil solution chemistry. - Forest Ecology and Management 174: 97-115.

[17] Dubrovsky, M., Svoboda, M.D., Trnka, M., Hayes, M.J., Wilhite, D.A., Zalud, Z., Hlavinka, P. (2009): Application of relative drought indices in assessing climate change impacts on drought conditions in Czechia. - Theoretical and Applied Climatology 96: $155-171$.

[18] Gash, J.H.C. (1979): An analytical model of rainfall interception by forests. - Quarterly Journal of the Royal Meteorological Society105: 43-55.

[19] Gershenson, A., Bader, N.E., Cheng, W. (2009): Effects of substrate availability on the temperature sensitivity of soil organic matter decomposition. - Global Change Biology 15 (1): $176-183$.

[20] Gracia, C., Sabate, S., Martinez, J.M., Albeza, E. (1999): Functional responses to thinning. - In: Rodá F., Retana J, Gracia C, Bellot J. (Eds.), Ecology of Mediterranean Evergreen Oak Forests. - Springer-Verlag, Heidelberg: 329-338.

[21] Granier, A., Lousteau, D., Breda, N. (2000): A generic model of forest canopy conductance dependent on climate, soil water availability and leaf area index. - Annals of Forest Science 57: 755-765.

[22] Grier, C.C., Running, S.W. (1977): Leaf area of mature Northwestern coniferous forests: relation to site water balance. - Ecology 58: 893-899.

[23] Högberg, P. (2010): Is tree root respiration more sensitive than heterotrophic respiration to changes in soil temperature? - New Phytologist 188 (1): 9-10.

[24] IUSS Working Group WRB, (2006): World reference base for soil resources 2006. $2^{\text {nd }}$ edition. World Soil Resources Reports No. 103. FAO, Rome. ISBN 92-5-105511-4,

[25] Janssens, I.A., Sampson, D.A., Curiel-Yuste, J., Carrara, A., Ceulemans, R. (2002): The carbon cost of fine root turnover in a Scots pine forest. - Forest Ecology and Management 168: $231-240$

[26] Jose, S., Gillespie, A.R. (1997): Leaf area-productivity relationships among mixedspecies hardwood forest communities of the central hardwood region. - Forest Science 43 (1): $56-64$.

[27] Juodvalkis, A., Kairiukstis, L., Vasiliauskas, R. (2005): Effects of thinning on growth of six tree species in north-temperate forests of Lithuania. - European Journal of Forest Research 124: 187-192.

[28] Knoche, D. (2005): Effects of stand conversion by thinning and underplanting on water and element fluxes of a pine ecosystem (P. sylvestris L.) on lignite mine spoil. - Forest Ecology and Management 212: 214-220.

[29] Kowalik, P.J., Borghetti, M., Borselli, L., Magnani, F., Sanesi, G., Tognetti, R. (1987): Diurnal water relation of beech (Fagus sylvatica L.) trees in the mountains of Italy. Agricultural and Forest Meteorology 84: 10-23.

[30] Kowalik, P.J., Eckersten, H. (1984): Water transfer from soil through plants to the atmosphere in willow energy forest. - Ecological Modelling 26: 251-284. 
[31] Kowalik, P.J., Turner, N.C. (1983): Diurnal changes in the water relations and transpiration of a soybean crop simulated during the development of water deficits. Irrigation Science 4: 225-238.

[32] Kuzyakov, Y. (2002): Separating microbial respiration of exudates from root respiration in non-sterile soils: a comparison of four methods. - Soil Biology \& Biochemistry 34 (11): 1621-1631.

[33] Lagergren, F., Lindroth, A. (2002): Transpiration response to soil moisture in Pine and Spruce trees in Sweden. - Agricultural and Forest Meteorology 112: 67-85.

[34] Lockow, K.W. (2003): The effect of thinning regimes on the dynamics of Scots pine stand development (in Polish, English summary). - Sylwan 9: 3-9.

[35] Long, J.N., Smith, F.W. (1990): Determinant of stemwood production in Pinus contorta var. latifolia forest: the influence of site quality and stand structure. - Journal of Applied Ecology 27: 847-856.

[36] Lüttschwager, D., Rust, S., Wulf, M., Forkert, J., Hüttl, R.F. (1999): Tree canopy and herb layer transpiration in three Scots pine stands with different stand structures. - Annals of Forest Science 56: 265-274.

[37] Mäkinen, H., Isomäki, A. (2004): Thinning intensity and growth of Scots pine stands in Finland. - Forest Ecology and Management 201: 311-325.

[38] Martin-Benito, D., Del Rio, M., Heinrich, I., Helle, G., Canellas, I. (2010): Response of climate-growth relationships and water use efficiency to thinning in a Pinus nigra afforestation. - Forest Ecology and Management 259: 967-975.

[39] Misson, L., Vincke, C., Devillez, F. (2003): Frequency responses of radial growth series after different thinning intensities in Norway spruce (Picea abies (L.) Karst.) stands. Forest Ecology and Management 177: 51-63.

[40] Morikawa, Y., Hattori, S., Kiyono. Y. (1986): Transpiration of a 31-year-old Chamaecyparis obtusa Endl. stand before and after thinning. - Tree Physiol. 2: 105-114.

[41] Müller, J., Bolte, A., Beck, W., Anders, S. (1998): Bodenvegetation und Wasserhaushalt von Kiefernforstökosystemen (Pinus sylvestris L.). - Verhandlungen der Gesellschaft für Ökologie 27: 407-414 (in German).

[42] Pukkala, T., Miina, J., Palahí, M. (2002): Thinning response and thinning bias in a young Scots pine stand.- Silva Fennica 36: 827-840.

[43] Raspe, S., Beuker, E., Preuhsler, T., Bastrup-Birk, A. (2010): Meteorological Measurements. Manual Part IX, 36 pp. In: Manual on methods and criteria for harmonized sampling, assessment, monitoring and analysis of the effects of air pollution on forests. - UNECE ICP Forests Programme Co-ordinating Centre, Hamburg. ISBN: 978-3-926301-03-1. [http://www.icpforests.org/Manual.htm]

[44] Stogsdill, W.R., Wittwer, R.F., Hennessey, T.C., Dougherty, P.M. (1992): Water-use in thinned loblolly-pine plantations. - Forest Ecology and Management 50: 233-245.

[45] Thibodeau, L., Raymond, P., Camire, C., Munson, A.D. (2000): Impact of precommercial thinning in balsam fir stands on soil nitrogen dynamics, microbial biomass, decomposition, and foliar nutrition. - Canadian Journal of Forest Research 30: 229-238.

[46] Valinger, E., Elfving, B., Mörling, T. (2000): Twelve-year growth response of Scots pine to thinning and nitrogen fertilisation. - Forest Ecology and Management 134: 45-53.

[47] Vesala, T., Suni, T., Rannik, U., Keronen, P., Markkanen, T., Sevanto, S., Gronholm, T., Smolander, S., Kulmala, M., Ilvesniemi, H., Ojansuu, R., Uotila, A., Levula, J., Makela, A., Pumpanen, J., Kolari, P., Kulmala, L., Altimir, N., Berninger, F., Nikinmaa, E., Hari, P. (2005): Effect of thinning on surface fluxes in a boreal forest. - Global Biogeochemical Cycles 19, GB2001, doi:10.1029/2004GB0023162005.

[48] Watson, D. (1947): Comparative physiological studies in the growth of field crops. I. Variation in net assimilation rate and leaf area between species and varieties, and within and between years. - Annals of Botany 11: 41-76. 
[49] Whitehead, D., Jarvis, P.G., Waring, R.H. (1984): Stomatal conductance, transpiration, and resistance to water uptake in a Pinus sylvestris spacing experiment. - Canadian Journal of Forest Research 14: 692-700.

[50] Zahner, R., Whitmore, F.W. (1960): Early growth of radically thinned loblolly pine. Journal of Forestry 58: 628-634.

[51] Zhu, B., Cheng, W. (2011): Rhizosphere priming effect increases the temperature sensitivity of soil organic matter decomposition. - Global Change Biology 17 (6): 21722183. 